\title{
Quantitative estimation of complex phosphate - solubilization by immobilized or free Azospirillum Lipoferum (H3) as vital vaccine in Pikovskaya broth (PVK) medium
}

Hafsa. M. E. Mohamed*

Department of Botany, Faculty of Science, Omar Al-Mukhtar University, Libya
Farag M. A. Shaieb

Department of Botany, Faculty of Science, Omar Al-Mukhtar University, Libya Ehwt2008@yahoo.com

\section{Hesham M. A. EL-Komy}

Department of Botany, Faculty of Science, ElMinia University, El-Minia, Egypt

https://doi.org/10.36602/jmuas.2019.v01.01.13

Key words: Azospirillum lipoferum, Phosphate solubilization, Pikovskaya broth (PVK) medium, (inorganic phosphate) $\mathrm{Ca}_{3}\left(\mathrm{po}_{4}\right)_{2}$.

\section{Introduction}

It is well known that a considerable number of bacterial species, mostly those associated with the plant rhizosphere, are able to exert a beneficial effect upon plant growth. Therefore, their use as biofertilizers or control agents for agriculture improvement has been a focus of numerous researchers for a number of years (Suslov, 1982; Glick, 1995). This group of bacteria has been termed 'plant growth promoting rhizobacteria' (PGPR) 
(Kloepper and Schroth, 1978). Solubilization of precipitated Tricalcium phosphate (TCP) in unbuffered solid agar medium plates has been used widely as the initial criterion for the isolation of phosphate solubilizing microorganisms (Pikovskaya,1948). Tricalcium phosphate (TCP) is regarded as a model compound for measuring the potential or relative rates of microbial solubilization of insoluble inorganic phosphate compounds. In addition, the insoluble calcium phosphate forms a major portion of insoluble phosphate in soil (Devi and Narasimhan, 1978).

\section{Materials and methods}

\section{Isolation of Azospirillum spp.}

Soil and plant root samples were collected from different regions at EL- Jabal ELAkhdar, Roots were cut into about $0.5-1 \mathrm{~cm}$ long segments. $0.1 \mathrm{~g}$ of the root pieces were introduced into a sterile test-tubes containing $4 \mathrm{ml}$ of the semisolid (DÖbereiner medium -DN) (DÖbereiner and pedrosa, 1987).

\section{Identification of the bacterial isolates}

Five isolates had a high (solubilization efficiency) on Pikovskaya (PVK) medium plate from different plants were recognized as belonging to the genus Azospirillum spp., according to morphological, cultural and some biochemical characteristics described by Tarrand et al., (1978), and the schemes described in the $9^{\text {th }}$ edition of Bergy's Manual of Systematic Bacteriology (Krieg and DÖbereiner, 1984).

\section{Biochemical tests}

Different biochemical tests were carried out : Nitrate reductase activity, catalase activity, growth in the presence of $3 \% \mathrm{Nacl}_{2}$, starch and gelatin hydrolysis were also tested, growth on succinate and pyruvate as sole carbon - source. For determination of the different species, utilization of different carbon-sources was performed in aerobic conditions. The organisms were grown in semisolid medium containing the carbohydrate together with a pH indicator (bromothymol blue) according to Hugh and Leifson, (1953). The development of a yellow color during 96 hour incubation at $30^{\circ} \mathrm{C}$ indicates acidification.

\section{Immobilization of Azospirillum lipoferum isolate $(\mathrm{H3})$ in alginate pellets}

A.lipoferum isolate (H3) which had high (solubilization efficiency) on Pikovskaya (PVK) medium on plate was immobilized by entrapment in $2 \%$ Ca-alginate. Cells encapsulated in alginate pellets were prepared by using the method applied at laboratory (Shaban and El-Komy, 2000; El- Komy, 2001; 2005). 


\section{Quantitative estimation of phosphate- solubilization by bacterial isolates in liquid Pikovskaya (PVK) medium containing insoluble phosphate (inorganic phosphate) Са3(po4) $)_{2}$ :}

Experiments were carried out in flasks $(100 \mathrm{ml})$ each flask containing $20 \mathrm{ml}$ of PVK medium, $\mathrm{pH}=7.0$, before autoclaving. Flasks were inoculated with either $1 \mathrm{ml}$ of bacterial suspension, $3.0 \mathrm{~g}$ or $2.7 \mathrm{~g}$ of fresh alginate agar beads containing $10^{9} \mathrm{CFU} /$ flask. The flasks were incubated at $30^{\circ} \mathrm{C}$ as still-surface culture. Cultures were harvested by centrifugation at $7000 \mathrm{x} g$ for $10 \mathrm{~min}, 2,4,6,8$ and 10 days after incubation, and the phosphorus in culture was estimated by the paramolybdate blue method using spectrophotometric at $(410 \mathrm{~nm})($ Olsen and Sommers, 1982). Phosphorus content was expressed as $(\mu \mathrm{g} / \mathrm{ml})$ and $\mathrm{pH}$ of the medium was recorded at the same time.

\section{Bacterial cell - free inoculum:}

For preparing the bacterial cell free inoculum, one $\mathrm{ml}$ of bacterial suspension was transferred into flask containing $50 \mathrm{ml}$ of Nutrient broth (NB) medium, incubated at $30^{\circ} \mathrm{C}$ for 24 hours.

\section{Results and discussion}

After several transfers for purifications, isolates were identified as bacteria belong to the genus Azospirillum according to the following common cultural and cell-morphological characteristic in semisolid (DN) medium, strains were Gram- negative motile, ovoid to curved-rods, and showed the presence of characteristic white sub-surface pellicles (often $10 \mathrm{~mm}$ ) below the surface of semisolid media. In the present study, Azospirillum spp. were isolated and enriched from the rhizosphere or free soil using the nitrogen-deficient medium (DN) which L-malic acid was the sole carbon-source (El-Komy, 1992).

Moreover, the cultural and morphological tests and some biochemical tests were proceeded, for example the acidification of different carbon sources by the tested bacteria according to the level of acidification of the $\mathrm{pH}$ indicator, (bromothymol-blue) to colour the reaction. The preference of the organic acids by different Azospirillum species was reported by Reinhold et al., (1985), and can be explained on the basis that organic acids were the major source of nutrients for microflora in the rhizosphere (Curl and Truelove, 1986). All strains were positive in nitrate reductase, catalse and motility activities and the isolates were negative in gelatin and starch hydrolysis. 


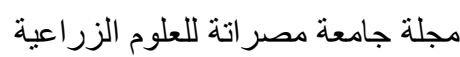

عدد خاص بالأوراق العلمية المقدمة للمؤتمر العلمي الأول للعلوم الزراعية ــ إنتاج نباتي (5-6 أكتوبر 2019)

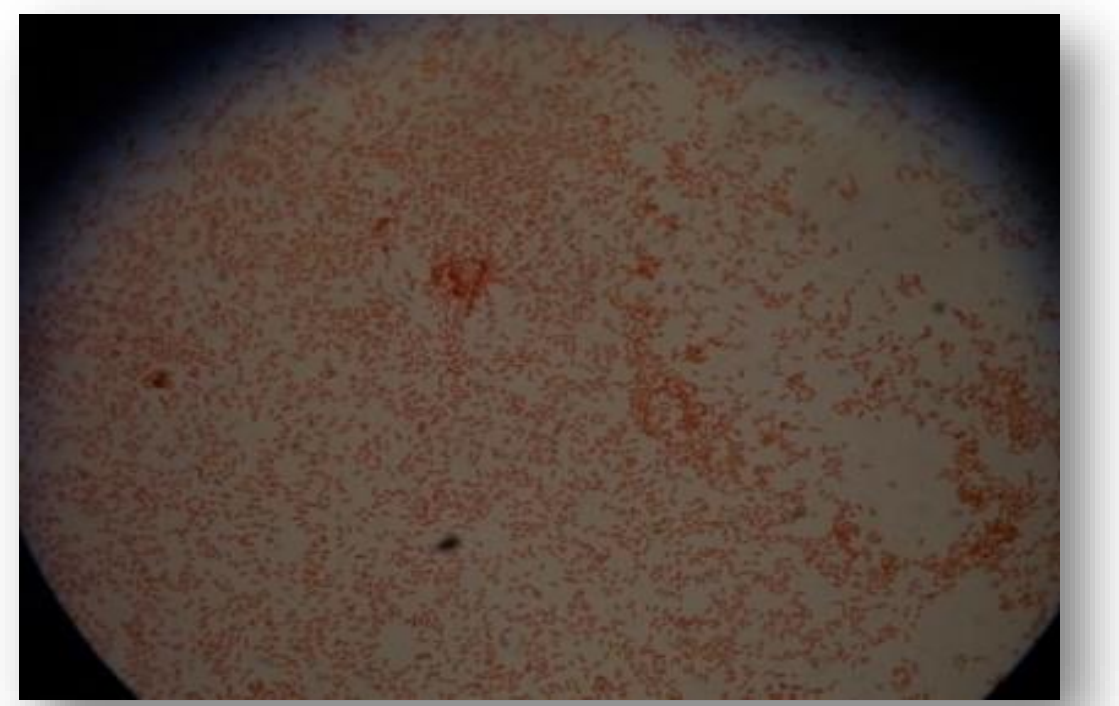

Figure (1) Gram staining of Azospirillum spp.

The results showed that Azospirillum lipoferum (H3) as free or immobilized bacteria which were further tested for their ability to solubilize tricalcium phosphate in (PVK) broth medium (Table.1). (Figure.2.3) to indirect measurement of phosphate solubilization by plate assay, the direct measurement of phosphate solubilization in (PVK) broth, which is more accurate results, especially for Azospirillum lipoferum strains (El-komy, 2005). As a result show on (PVK) broth inoculated with free bacterial formulation of Azospirillum lipoferum (H3) and the count of the bacteria recorded $19.5 \times 10^{9} \mathrm{CFU}$ which increased on the first $2^{\text {nd }}$ and $4^{\text {th }}$ day as $8.8(\mu \mathrm{g} / \mathrm{ml})$ and $6.9(\mu \mathrm{g} / \mathrm{ml})$ of free phosphorus (Figure 2) which determined spectrophotometric and declined slowly after words on the 8,9 and $10^{\text {th }}$ day after incubation, $\mathrm{pH}$ values were determined which decreased gradually in (PVK) broth during early days of incubation and no increase was observed in latter days, maximum $\mathrm{pH}$ recorded 6.00 on $10^{\text {th }}$ day (Table.2). Data presented in (Figure. 3) showed that phosphate solubilization by the immobilized bacteria in (PVK) broth medium and the count of the bacteria recorded $16 \times 10^{9} \mathrm{CFU}$ which increased slowly from $2^{\text {nd }}$ day $2.4(\mu \mathrm{g} / \mathrm{ml})$ to the $10^{\text {th }}$ day $3.7(\mu \mathrm{g} / \mathrm{ml})$ of phosphorus without any increase latter compared with free bacterial cell- suspension in (PVK) broth. Earlier reduction in $\mathrm{pH}$ values was also observed in (PVK) broth when bacterial strains used in the immobilized forms. $\mathrm{pH}$ was recorded 5.62 on the $2^{\text {nd }}$ day an decreased gradually to 4.47 on the $10^{\text {th }}$ day after incubation (Table.2. Figure 4,5).

In general, Ca-phosphate solubilization seems to be linked with $\mathrm{pH}$ decrease of the medium but this $\mathrm{pH}$ decrease was not strictly proportional to the amount of the phosphate solubilized. These findings were supported by other reports (Illmer and Schinner, 1992). 
Table (1) Quantitative estimation of phosphate - solubilization by immobilized or free bacterial isolates in liquid PVK medium.

\begin{tabular}{|c|c|c|c|}
\hline \multirow{2}{*}{ Isolate } & $\begin{array}{c}\text { Incubation } \\
\text { day }\end{array}$ & $\begin{array}{c}\text { Immobilized bacteria } \\
\mathbf{P}(\boldsymbol{\mu g} / \mathbf{m l})\end{array}$ & $\begin{array}{c}\text { free bacteria } \\
\mathbf{P}(\boldsymbol{\mu g} / \mathbf{m l})\end{array}$ \\
\hline \multirow{3}{*}{$\begin{array}{c}\text { A.lipoferum } \\
\text { H3 }\end{array}$} & $\mathbf{2}$ & 2.48 & 8.81 \\
\cline { 2 - 4 } & $\mathbf{4}$ & 3.20 & 6.94 \\
\cline { 2 - 4 } & $\mathbf{6}$ & 3.27 & 4.93 \\
\cline { 2 - 4 } & $\mathbf{8}$ & 3.48 & 4.21 \\
\cline { 2 - 4 } & $\mathbf{1 0}$ & 3.70 & 4.49 \\
\hline
\end{tabular}

Table (2) pH values of A.lipoferum (H3) in (PVK) broth and (SE) of immobilized A.lipoferum (H3) on (PVK) solid media.

\begin{tabular}{|c|c|c|c|}
\hline \multirow{2}{*}{ Isolate } & \multirow{2}{*}{$\begin{array}{c}\text { Incubation } \\
\text { day }\end{array}$} & Free isolate & Immobilized isolate \\
\cline { 2 - 4 } & 2 & 6.85 & 5.62 \\
\hline \multirow{3}{*}{$\begin{array}{c}\text { A.lipoferum } \\
\text { H3 }\end{array}$} & 4 & 6.21 & 5.23 \\
\cline { 2 - 4 } & 6 & 6.14 & 4.75 \\
\cline { 2 - 4 } & 8 & 6.06 & 4.71 \\
\cline { 2 - 4 } & 10 & 6.00 & 4.47 \\
\hline
\end{tabular}

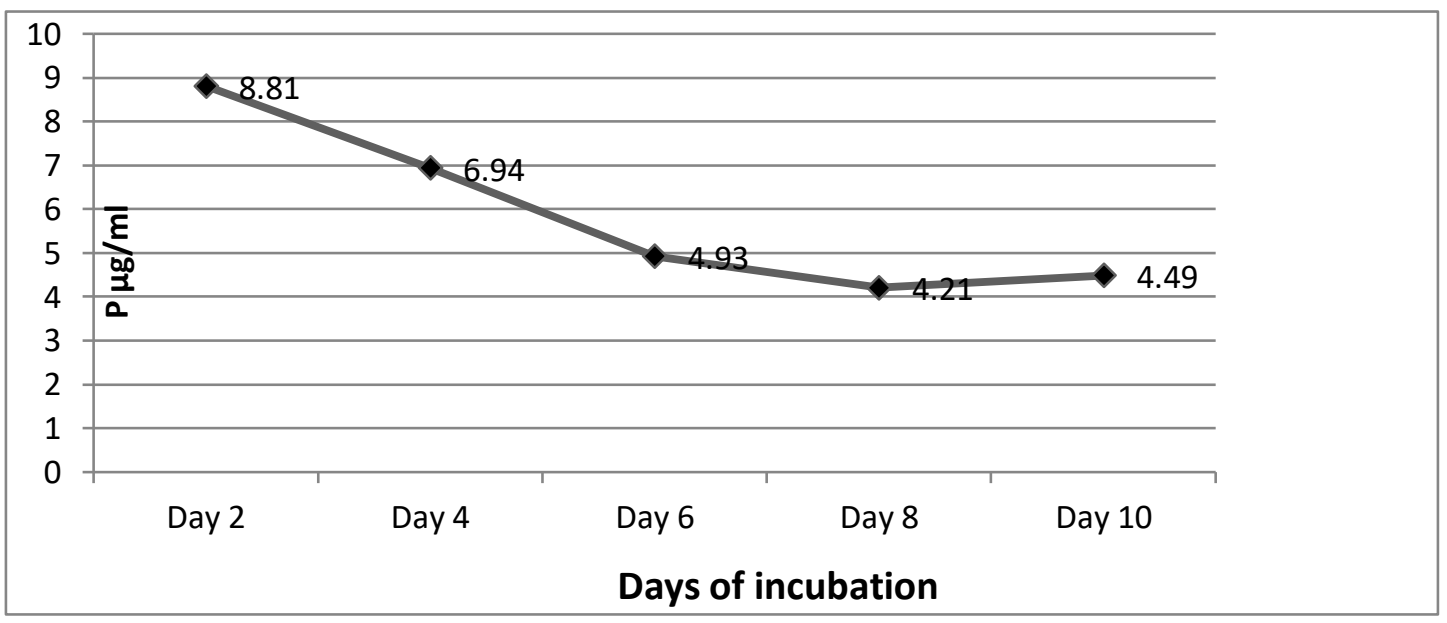

Figure (2) Phosphate-solubilization by A.lipoferum (H3) free bacterial isolates in liquid (PVK) medium. 


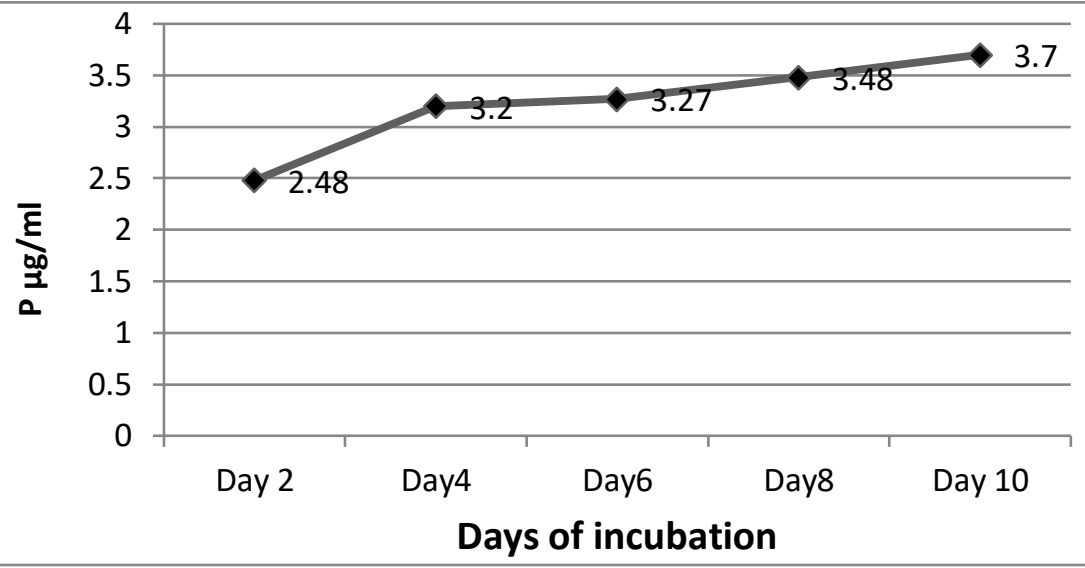

Figure (3) Phosphate-solubilization by A.lipoferum(H3) immobilized bacterial isolates in liquid (PVK) medium

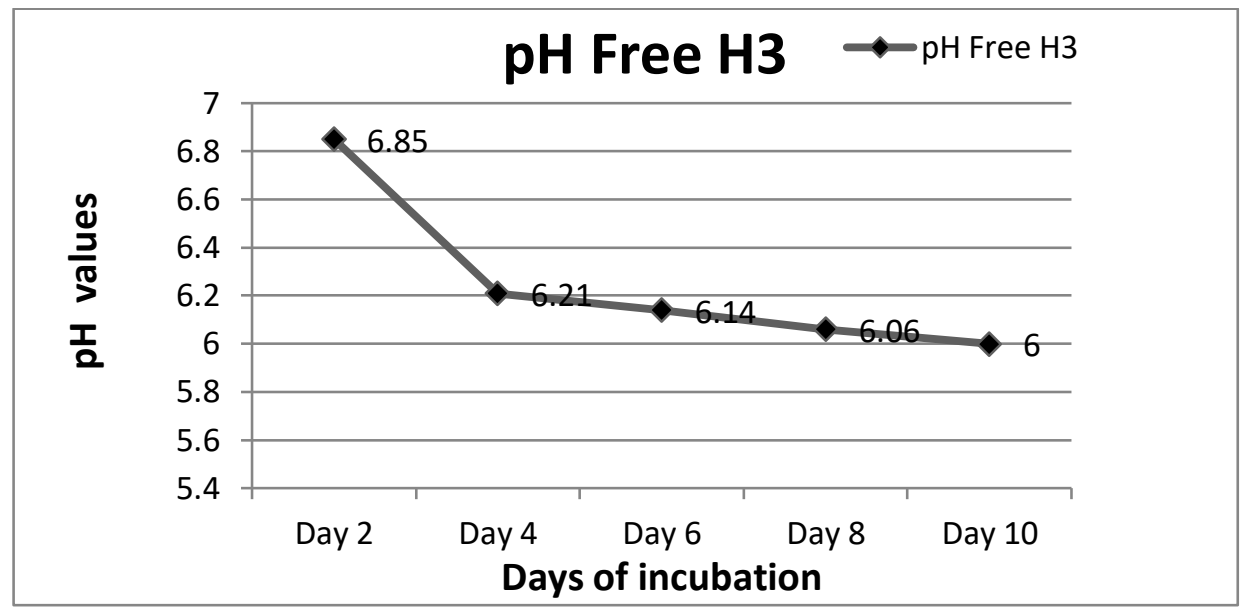

Figure (4) pH values of free A.lipoferum (H3) in (PVK) broth

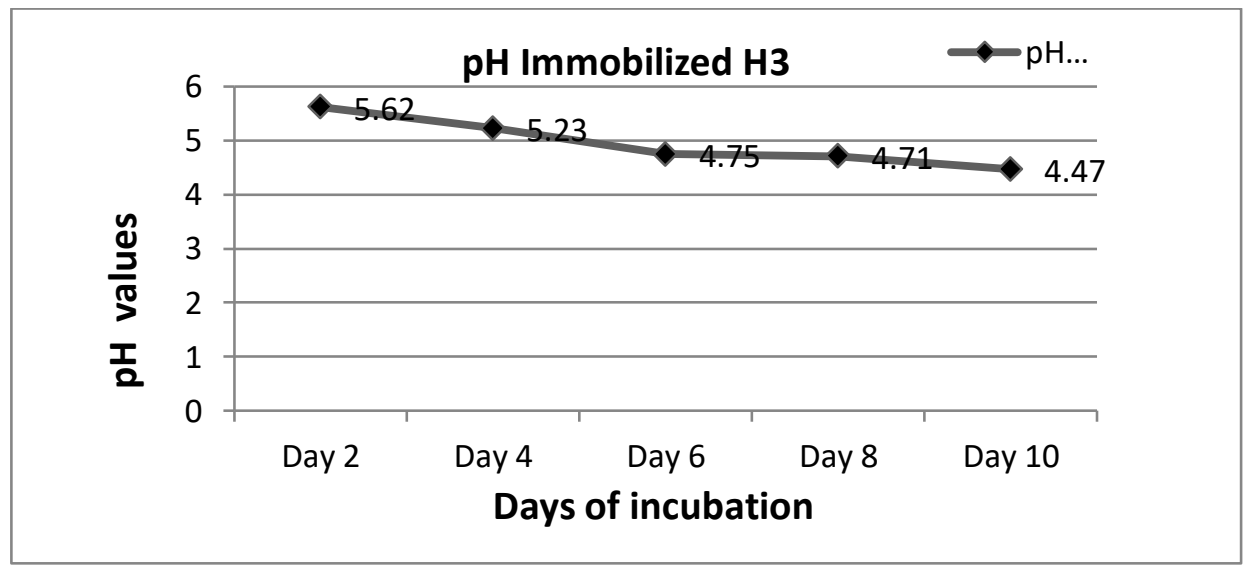

Figure (5) pH values of immobilized A.lipoferum (H3) in (PVK) broth 


\section{References}

Curl, E.A. and Truelove, B. (1986): The rhizosphere, Springer- verlag. Berlin. P.55 - 92.

Devi, M.P. and Narasimhan, R.L. (1978): phosphate and lime potentials of some alluvial soils. J. Indian. Soc. Soil. Sci. 26, 33- 37.

Döbereiner, J. and Pedrosa, F.O. (1987): Nitrogen-fixing bacteria in Nonleguminous crop plants. Brock/Springer series in contemporary/Bioscience. P, 155.

El-Komy, H.M. (1992): Ecological and physiological studies on the rhizosphere of maize and rice plants. Ph. D. Thesis. Institute of Agricultural Microbiology Russian Acad. Agr. Sci., Sankt Peterburg.pp 169.

El-Komy, H. (2001): Survival of and wheat- root colonization by alginate encapsulated Herbaspirillum spp. Flia. Microbio. 46:25- 30.

El-Komy, H.M. (2005): Coimmobilization of Azospirillum lipoferum and Bacillus megaterium for successful phosphorus and nitrogen nutrition of wheat plants. Food Technol. Biotechnol.43: 19-27.

Glick, B.R., (1995): The enhancement of plant growth by free-living bacteria. Can. J. Microbiol. 41, 109-117.

Hugh, R. and Leifson, E. (1953): The taxonomic significance of various fermentative versus oxidative metabolism of carbohydrates by Gram- negative bacteria. J. Bacter. 66: 24-26.

Illmer, P. and Schinner, F. (1992): Solubilisation of inorganic calcium phosphate solubilization mechanisms. Soi.l Biol. Biochem; 27:257-263.

Kloepper, J.W. and Schroth, M.N. (1978): Plant growth-promoting rhizobacteria on radishes. In: Station de Pathologie vegetale et Phyto-bacteriologie, editor. Proceedings of the 4th International Conference on Plant Pathogenic Bacteria Vol II. Tours: GilbertClary, pp. 879-82.

Krieg, N. R. and Döbereiner, J. (1984): Genus Azospirillum. In, Holt, J.G., and Krieg, N. R. (eds), Bergey's Manual of Systematic Bacteriology $9^{\text {th }}$ ed, V.1 Williams and Wilking, Baltimore, pp. 94-104.

Olsen, S.R. and Sommers, L.E. (1982) Phosphorus. In: Methods of Soil Analysis, Part2, A.L. Page, R.H. Miller, D.R. Keeeny (Eds.), American Society of Agronomy, Madison, Wisconsin pp. 403-430.

Pikovskaya, R.I. (1948): Mobilization of phosphorus in soil in connection with the vital activity of some microbial species, Microbiologiya, 17: 362-370. 
Reinhold, B.; Hurek, T. and Fendrik, I. (1985): Strain-specific chemotaxis of Azospirillum spp. J Bacteriol 162:190-195.

Shaban,G. and El-Komy, H. (2000): Survival and proliferation of alginate encapsulated Trichoderma in Egyption soil. Mycopath. 151: 139- 146.

Suslov, T.V. (1982): Role of root-colonizing bacteria in plant growth. In: Mount MS, Lacy GH, editors. Phytopathogenic Prokariotes. London: Academic Press, pp. 187-223.

Tarrand, J.J.; Kreig, N.R. and DÖbereiner, J. (1978): A taxonomic study of the spirillum lipoferum group, with a description of a new genus, Azospirillum gen. nov. and two species, Azospirillum lipoferum (Beijerink) comb. Nov. and Azospirillum lipoferum sp. Nov. can. J. Microbiol.24:967 - 980.

\section{Azospirillum Lipoferum H3 التقدير الكمي لذوبان الفوسفات المعقد بواسطة بكتيريا}

Pikovskaya (PVK) الحرة والمكبسلة كلقاح حيوي في مرق

Hafsa. M. E. Mohamed*

Department of Botany,

Faculty of Science, Omar Al-

Mukhtar University, Libya
Farag M. A. Shaieb

Department of Botany,

Faculty of Science, Omar Al-

Mukhtar University, Libya
Hesham M. A. EL-Komy

Department of Botany, Faculty of Science, El-Minia University, El-Minia, Egypt

Ehwt2008@yahoo.com

https://doi.org/10.36602/jmuas.2019.v01.01.13

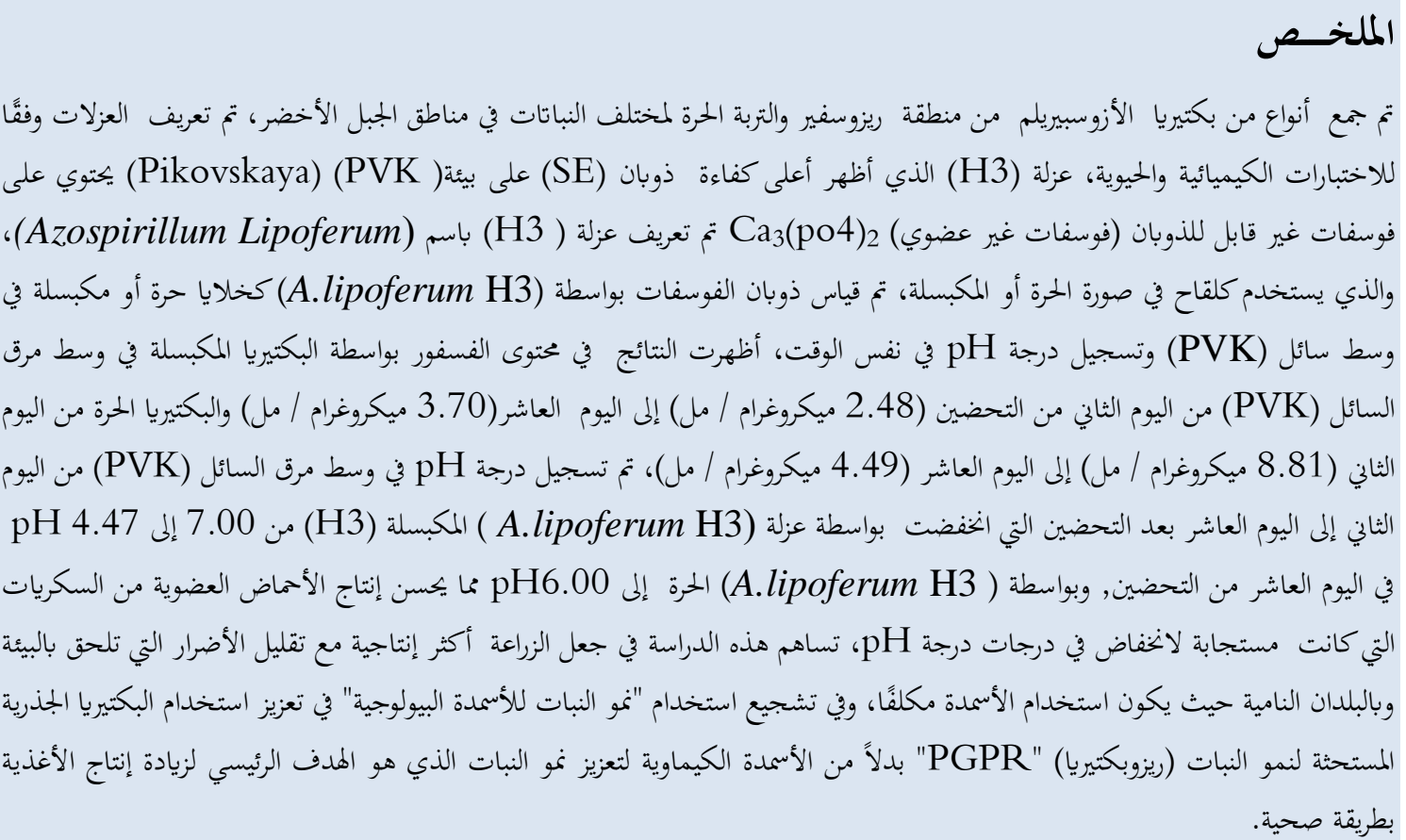

